\title{
TANGGUNG JAWAB PENDIRI PERSEROAN TERBATAS
}

\author{
Oleh: \\ Vesmin Jani
}

Dalam mendirikan Perseroan Terbatas, maka harus memenuhi syarat-syarat pendirian Perseroan Terbatas. Syarat-syarat pendirian Perseroan Terbatas menurut Pasal 7 Undang-Undang Nomor 40 Tahun 2007, mencantumkan bahwa perseroan didirikan oleh 2 (dua) orang atau lebih dengan akta notaris yang dibuat dalam bahasa Indonesia. Akan tetapi, yang menjadi permasalahan yang dibahas yaitu mengenai perbuatan hukum yang dilakukan oleh pendiri sebelum Perseroan Terbatas didirikan atau berbadan hukum.

Perbuatan hukum yang dilakukan calon pendiri untuk kepentingan perseroan yang belum didirikan, mengikat Perseroan setelah perseroan menjadi badan hukum apabila Rapat Umum Pemegang Saham (RUPS) pertama perseroan secara tegas menyatakan menerima atau mengambil alih semua hak dan kewajiban yang timbul dari perbuatan hukum yang dilakukan oleh calon pendiri atau kuasanya. RUPS ini merupakan RUPS pertama yang harus diselenggarakan dalam jangka waktu paling lambat 60 (enam puluh) hari setelah perseroan memperoleh status badan hukum. Setiap calon pendiri yang melakukan perbuatan hukum tersebut bertanggung jawab secara pribadi atas segala akibat yang timbul.

Perbuatan hukum atas nama perseroan yang belum memperoleh status badan hukum, hanya boleh dilakukan oleh semua anggota Direksi bersama-sama semua pendiri serta semua anggota Dewan Komisaris Perseroan dan mereka semua bertanggung jawab secara tanggung renteng atas perbuatan hukum tersebut. Sedangkan jika perbuatan tersebut dilakukan oleh pendiri Perseroan Terbatas atas nama Perseroan yang belum memperoleh status badan hukum, perbuatan hukum tersebut menjadi tanggung jawab pendiri yang bersangkutan dan tidak mengikat Perseroan. Sehingga perbuatan hukum yang dilakukan oleh pendiri Perseroan Terbatas ini, hanya mengikat dan menjadi tanggung jawab perseroan setelah perbuatan hukum tersebut disetujui oleh semua pemegang saham dalam RUPS yang dihadiri oleh semua pemegang saham perseroan. Perbuatan pidana yang dilakukan oleh Direksi dan/atau pendiri pada kegiatan perseroan ini menurut Dalinama Telaumbanua merupakan perbuatan pidana korporasi.

Sebagai persekutuan modal, kekayaan Perseroan Terbatas terdiri dari modal yang seluruhnya terbagi dalam bentuk saham. Para pendiri Perseroan Terbatas berkewajiban untuk mengambil bagian modal itu dalam bentuk saham dan mereka mendapat bukti surat saham sebagai bentuk penyertaan modal. Tanggung jawab para pemegang saham terbatas hanya pada modal atau saham yang dimasukkannya ke dalam perseroan. 
Segala hutang perseroan tidak dapat dibebani kepada harta kekayaan pribadi para pemegang saham, melainkan hanya sebatas modal saham para pemegang saham itu yang disetorkan kepada perseroan.

\section{Referensi}

Abdul Saliman, dkk. (2005). Hukum Bisnis Untuk Perusahaan. Jakarta: Kencana Renada Media Group.

Telaumbanua, Dalinama. 2015. "PERTANGGUNGJAWABAN PIDANA KORPORASI DI BIDANG LINGKUNGAN HIDUP”. Refleksi Hukum: Jurnal Ilmu Hukum 9 (1), 101-12. https://doi.org/https://doi.org/10.24246/jrh.2015.v9.i1.p101-112.

Undang-Undang Republik Indonesia Nomor 40 Tahun 2007 tentang Perseroan Terbatas.

http://optikonline.info/2010/o3/12/cara-pendirian-perseroan-terbatas-pt.html http://lhslawfirm.blog.com/2010/11/14/keabsahan-perbuatan-hukum-para-pendiri-pt/ http://www.lawindo.biz/prosedurpendirianpt.htm 